\title{
Instagram TV: Konvergensi Penyiaran Digital dan Media Sosial
}

\author{
${ }^{1}$ Bianca Michelle Datubara, ${ }^{2}$ Irwansyah \\ ${ }^{1}$ Fakultas Ilmu Sosial dan Ilmu Politik Universitas Indonesia, Jakarta 10430 \\ ${ }^{2}$ Ilmu Komunikasi FISIP UI, Jakarta 10430 \\ E-mail: ${ }^{1}$ biancamichelledb@gmail.com; ${ }^{2}$ dr.irwansyah.ma@gmail.com
}

\begin{abstract}
Abstrak. Seiring dengan perkembangan internet, adanya penggabungan antara satu platform dengan platform lainnya melahirkan fitur baru yang digemari masyarakat, termasuk platform Sosial TV. Sosial TV menghadirkan kesempatan bagi masyarakat untuk membuat saluran TV milik pribadi yang dapat dipertontonkan secara cepat dan massive. Melalui konten yang disajikan oleh sosial TV, penonton melakukan komunikasi secara langsung sambil menonton sosial TV tersebut. Salah satu contoh Sosial TV di Indonesia adalah Instagram TV. Instagram TV merupakan bentuk konvergensi media. Konvergensi media, bagaimanapun, dimulai dan dimungkinkan oleh teknologi digital (Huang et al., 2006). Belum adanya regulasi yang mengatur Sosial TV membuat masyarakat seakan dapat bertindak bebas dalam memproduksi konten di Instagram TV tanpa mengindahkan dampak-dampak yang akan terjadi, seperti komentar-komentar yang bisa dituliskan dengan bebas, maupun konten yang diproduksi. Penelitian ini menggunakan metode kualitatif berbasis teks dengan wawancara sebagai teknik pengumpulan data untuk menunjukkan fenomena Sosial TV IG TV menjadi dampak dari broadcasting digital. Hasil dari penelitian ini adalah Instagram TV adalah salah satu contoh nyata adanya konvergensi dari penyiaran digital dan media sosial. Salah satu dampak dari adanya konvergensi penyiaran digital dan media sosial ini adalah pergeseran penonton dari konvensional ke digital. Dampak dari konvergensi perlu diawasi, salah satunya dengan regulasi.
\end{abstract}

Kata kunci: Social TV, Instagram, Internet

\begin{abstract}
Along with the development of the internet, the existence of merger between one platform with another platform bring new features favored by the community, including the Social TV platform. Social TV presents an opportunity for the community to make privately owned TV channel that can be watched quickly and massively. Through content presented by social TV, the audience communicates directly while watching the social TV. One example of Social TV in Indonesia is Instagram TV. Instagram TV is a form of media convergence. Media convergence, however, was initiated and made possible by digital technology (Huang et al., 2006). The absence of regulations governing Social TV makes it seem as if the community can act freely in producing content on Instagram TV without regard to the impacts that will occur, such as comments that can be written freely, or the content produced. This study uses a text-based qualitative method with interviews as a data collection technique to show the phenomenon of Social TV IG TV being the impact of digital broadcasting. The results of this study are Instagram Tv is a clear example of the convergence of digital broadcasting and social media. One impact of the convergence of digital broadcasting and social media is the shift of viewers from conventional to digital. The impact of convergence needs to be monitored, one of the examples is with regulation.
\end{abstract}

Keyword: Social TV, Instagram, Internet

DOI: https://doi.org/10.29313/mediator.v12i2.4778 


\section{PENDAHULUAN}

Memasuki era revolusi industri 4.0 dan berkembangnya internet di seluruh dunia membuat media sosial menjadi media utama bagi masyarakat dalam mencari informasi. Tidak hanya itu, media sosial digunakan oleh masyarakat untuk berbagai macam kegiatan, termasuk hiburan. Hal ini diperkuat dengan definisi media sosial yakni media sosial adalah alat berbasis web untuk interaksi yang, di samping percakapan, memungkinkan pengguna untuk berbagi konten seperti foto, video, dan tautan (Boyd \& Ellison, 2008). Aktivitas penggunaan internet untuk mengakses media sosial di Indonesia terbilang cukup tinggi. Menurut We Are Social Tahun 2019, dari 268,2 juta penduduk di Indonesia, sampai dengan Januari 2019 pengguna internet di Indonesia mencapai 150 juta orang dengan angka peneterasi $56 \%$. Hal ini setara dengan peneterasi penggunaan media sosial pada angka $56 \%$ dan 150 juta orang penggunanya di Indonesia. Pengguna internet di Indonesia meningkat kurang lebih $13 \%$ atau sebanyak 17 juta orang dalam rentang waktu Januari 2018 sampai dengan Januari 2019. Data yang diperoleh We Are Social 2019 ini menunjukkan bahwa seiring bertambahnya tahun, bertambah pula minat manusia untuk menggunakan media sosial guna memenuhi kebutuhan informasinya sehari-hari.

Menurut We Are Social 2019, di Indonesia, masyarakat rata-rata menggunakan internet selama 8 jam 36 menit sehari. Waktu tersebut digunakan untuk mengakses internet dari berbagai macam alat. We Are Social 2019 juga menyebutkan bahwa untuk mengakses media sosial, masyarakat Indonesia menghabiskan waktu selama 3 jam 26 menit sehari dari berbagai macam device dan 2 jam 52 menit sehari untuk menonton secara streaming. Pergeseran analog ke era digital seperti saat ini menciptakan pilihan lain bagi masyarakat untuk menikmati hiburan. Menurut Binns (2019) platform televisi didefinisikan selama bertahun-tahun oleh dua hal: posisi singular di rumah, dan linearitas siarannya. Pada 1974, Raymond Williams menguraikan bagaimana televisi mewarisi format media yang lebih tua, seperti berita, acara bincang-bincang, olahraga, iklan, dan drama dari radio; tetapi juga, bagaimana platform menciptakan bentuk hibrida seperti drama-dokumenter dan variasi (Binns, 2019). Saat ini TV streaming menjadi salah satu pilihan masyarakat untuk menonton, selain yang biasa dilakukan di televisi ataupun bioskop. TV streaming dianggap lebih praktis dan mempunyai banyak pilihan program karena TV streaming merupakan produk berbasis internet. Layanan dan penggunaan video maupun TV streaming video berdasarkan koneksi internet, tentu juga menawarkan fleksibilitas dan interaksi yang lebih besar melalui koneksi internet dua arah. Proliferasi aplikasi seluler dengan kemampuan streaming video berarti bahwa lalu lintas video seluler dengan cepat menjadi bentuk dominan dalam jaringan seluler ( $\mathrm{Li}$, Zhang, \& Yuan, 2011). Video maupun TV yang disajikan dalam bentuk streaming biasanya memiliki kecepatan dan gambar yang lebih jernih dibandingkan TV kontemporer. Namun kelemahannya, penonton harus memili koneksi internet yang stabil untuk menonton video dengan lebih nyaman.

Tentu saja, dalam lanskap media kontemporer, siaran televisi bersaing dengan platform media lainnya. Pertumbuhan TV streaming terus berkembang dari tahun ke tahun. Awalnya, TV streaming hanya dapat diakses pada komputer atau laptop, namun sekarang kemajuannya sudah bertambah pesat dan telepon seluler atau smartphone menjadi media alternatif untuk menonton TV streaming. Bahkan sekarang, media 
Bianca Michelle Datubara, dkk. Instagram TV: Konvergensi Penyiaran Digital...

sosial sudah mulai memasukan unsur video streaming dan bahkan unsur TV ke dalamnya. Informa Telecoms \& Media (2008) menyebutkan bahwa penurunan ekonomi global belum dapat mengubah perkiraan optimis potensi pertumbuhan tinggi TV seluler dalam waktu dekat. Asia dianggap sebagai sarang pengembangan TV streaming dan TV seluler karena gaya hidup masyarakat di Asia dan penetrasi telepon seluler yang tinggi dan teknologinya yang sudah berkembang (Lin, 2018). Menurut TechinAsia 2018, pengguna smartphone di Indonesia adalah sebanyak 103 juta orang (Millward, 2014). Angka ini menunjukkan bahwa pengguna smartphone yang bersifat aktif meningkat hampir dua kali lipat sejak tahun 2013. Sedangkan di dunia, pengguna smartphone aktif berada di angka 2,56 milyar orang di seluruh dunia (Millward, 2014). Dari data yang diberikan, Indonesia diperkirakan akan melampaui sesama negara berkembang lainnya termasuk Brazil dalam hal smartphone pada beberapa tahun ke depan. Hal ini lah yang mendukung aktivitas-aktivitas lain yang akan dijalankan dan diciptakan dengan basis internet dan media sosial menjadi mudah diminati oleh sebagian besar orang.

Penyebaran TV seluler berbasis internet berskala besar menghadirkan peluang dan tantangan luar biasa bagi operator seluler dan penyedia teknologi. Penyedia layanan internet atau broadband berlomba-lomba memberikan kualitas terbaik dan kecepatan internet yang tinggi untuk memberikan kenyamanan pada masyarakat saat menggunakan internet dan mendukung perkembangan industri teknologi komunikasi. Pernyataan ini sejalan dengan yang dikatakan oleh Garfield dan Watson (1997) bahwa memiliki infrastruktur jaringan yang berkembang sangat penting untuk mengembangkan ekosistem teknologi informasi dan komunikasi (TIK) yang lebih baik (Choi, Wong, Chang, \& Park, 2016) fibre-optic technologies, and hybrid \\nfibre coaxial (HFC).

Media sosial seperti YouTube atau Facebook, Twitter, Instagram, dan lainnya kini juga semakin lazim dan menjadi lebih populer dan mulai menggabungkan teknologi streaming ke dalam fitur mereka. Pertumbuhan video steraming dan kemampuan smartphone untuk menyediakan konten TV streaming langsung kepada pengguna seluler menjadi kesempatan besar bagi masyarakat untuk menikmatinya. TV seluler serta aplikasi yang menyediakan fitur tersebut sampai saat ini telah tersebar di seluruh dunia (Li, Zhang, \& Yuan, 2011). Baik teknologi penyiaran digital maupun teknologi data nirkabel berbasis internet dapat digunakan untuk mendukung penyebaran TV seluler di dunia.

Konvergensi media lebih dari sekadar pergeseran teknologi. Konvergensi mengubah hubungan antara teknologi, industri, pasar, genre, dan audiens yang ada. Konvergensi mengacu pada suatu proses, tetapi bukan titik akhir. Berkat proliferasi saluran dan portabilitas komputasi baru dan teknologi telekomunikasi, masyarakat memasuki era di mana media akan ada di mana-mana dan akan menggunakan semua jenis media terkait dengan satu sama lain. Ponsel bukan hanya perangkat telekomunikasi tetapi juga memungkinkan untuk bermain game, mengunduh informasi dari internet dan mengirim foto (Jenkins, 2004).

Penggabungan antara satu platform ke platform lainnya menjadi bukti bahwa teknologi komunikasi akan memberikan kemudahan bagi hidup manusia, baik untuk memperoleh informasi maupun hiburan. Implikasi dari perkembangan infrastruktur berbasis teknologi komunikasi dan informasi pada adopsi keseluruhan tinjauan ke masa depan strategis dan struktur pasar 
foresight menarik untuk dipertimbangkan. Begitu pula tentang penggabungan media sosial yang sekarang menjadi platform untuk menonton video secara streaming. Bahkan beberapa platform media sosial turut membubuhkan nama TV pada fitur video streaming mereka untuk meyakinkan bahwa fitur tersebut mengandung sifat-sifat yang dimiliki oleh televisi konvensional.

Salah satu contoh pengabungan platform yang sudah nyata dilakukan adalah penggabungan media sosial dengan media kontemporer televisi atau yang biasa disebut dengan sosial TV. Beberapa media sosial telah menciptakan sosial TV sebagai salah satu media pemenuhan informasi masyarakat, contohnya Instagram TV yang diproduksi oleh platform media sosial Instagram.

\section{METODE}

Metode yang digunakan pada penelitian ini adalah pendekatan kualitatif berbasis teks. Metode kualitatif dipengaruhi oleh paradigma naturalistikinterpretatif Weberian, perspektif postpositivistik, kritis, dan post-modernisme. Peneliti pada penelitian kualitatif memulai dengan cara yang umum seperti topik-topik umum dan ide yang samar sehingga dapat disempurnakan dan diperjelas menjadi konsep yang lebih tepat ketika peneliti melakukan penelitian (Neuman, 2017). Biasanya, penelitian kualitatif mengamati proses, peristiwa, dan otentisitas dalam setiap kejadiannya (Somantri, 2004).

Pada penelitian ini, penulis mengumpulkan data melalui observasi dan wawancara mendalam. Observasi dilakukan dengan mengamati bagaimana perilaku pengunggah dan penonton pada Sosial TV, khususnya di media sosial Instagram. Nasution (1988) menyatakan bahwa observasi adalah dasar semua ilmu pengetahuan. Para ilmuwan hanya dapat bekerja berdasarkan data, yaitu fakta mengenai dunia kenyataan yang diperoleh melalui observasi (Sugiyono 2009: 226). Penulis juga mewawancarai Koordinator Litbang Komisi Penyiaran Indonesia (KPI) Pusat, Andi Andrianto untuk melihat bagaimana Sosial TV mulai diminati dan menyaingi televisi konvensional.

\section{TEMUAN DAN PEMBAHASAN}

Sosial TV dapat diartikan sebagai kombinasi atau penggabungan antara TV kontemporer dan media sosial. Sosial TV memungkinkan interaksi sosial diantara penonton dan pelaku produksi. Hal ini merupakan cara baru dan berbeda. Dalam aspek ini, sosial TV dapat disebut sebagai platform canggih untuk media sosial dengan menggunakan internet sebagai media komunikasi (Shin, 2013). Biasanya media sosial hanya menjadi platform bagi masyarakat untuk berkomunikasi dan menunjukkan eksistensinya kepada para pengikutnya melalui unggahanunggahannya. Namun, media sosial sekarang memberikan kesempatan kepada masyarakat untuk mendapatkan informasi dan hiburan secara lebih jauh lagi.

Lim (2015) juga menjelaskan
sosial TV didefinisikan sebagai komunikasi backchannel real-time di situs jejaring sosial (Hwang \& Lim, 2015) Melalui konten yang disajikan oleh sosial TV, penonton melakukan komunikasi secara langsung sambil menonton sosial TV tersebut. Menariknya, penonton sosial TV sosial memang mengatakan bahwa mereka menikmati berbagi pemikiran dan pendapat mereka dengan orang lain di media sosial daripada hanya menonton TV (Doughty et al., 2012). Melalui kenyataan tersebut, dapat diketahui bahwa ada alasan dari masyarakat secara nyata mengapa masyarakat memilih untuk terlibat dalam menonton sosial TV (Kim, Yang, \& Kim, 2019).

Salah satu strategi dari sosial TV 
adalah membangun hubungan dengan audiens, mengarahkan percakapan tentang pemrograman, dan meningkatkan rating atau nilai dari pemilik-pemilik akun sosial TV. Melalui sosial TV, penonton dapat berinteraksi dengan penonton lainnya melalui komentarkomentar yang diberikan secara langsung kepada konten yang dimuat oleh si content creator. Penonton dari sosial TV merasa mereka seolah-olah bersama saat interaksi dilakukan dengan cara memberikan komentar pada konten yang mereka tonton. Hal ini mengakibatkan pengguna media sosial merasakan pengalaman komunal dengan berinteraksi atau berkomunikasi secara berkelompok walaupun tidak bertemu secara fisik. Pengalaman seperti ini dapat dijelaskan oleh perasaan kehadiran sosial. Kehadiran sosial didefinisikan sebagai feeling atau 'perasaan bahwa aktor lain secara bersama-sama terlibat dalam interaksi yang dilakukan secara komunikatif' (Hwang \& Lim, 2015).

Menonton sosial TV dapat dilalui dengan menggunakan beberapa platform komunikasi. Secara umum, ada dua jenis platform yang biasanya digunakan oleh penonton sosial TV, yakni publik dan pribadi. Platform komunikasi publik merujuk pada seperangkat alat dan layanan yang memungkinkan melakukan percakapan terbuka dengan orang lain, seperti umpan berita Twitter dan timeline Facebook. Di sisi lain, platform pribadi merujuk pada platform yang memungkinkan pengguna untuk melakukan percakapan dengan orangorang seperti pesan teks atau SMS dan WhatsApp.

Namun, media sosial sekarang turut menjadi platform yang paling diminati masyarakat untuk menonton sosial TV. TechInAsia 2018 menyebutkan, penetrasi penonton televisi dengan minat masyarakat menonton Youtube sudah hamper sama, dengan penetrasi penonton televisi pada $57 \%$ dan penonton Youtube pada 53\% (Millward, 2014). Pasalnya, melalui sosial TV yang ada di media sosial seperti Youtube maupun Instagram, masyarakat dapat memilah-milah konten mana yang ingin mereka tonton sesuai dengan orang atau public figure yang mereka ikuti atau follow di media sosial tersebut. Tidak hanya public figure saja, masyarakat awam di media sosial pun turut dapat menciptakan kontennya sendiri dan menciptakan sosial TV milik mereka. Bahkan, melalui situs media sosial yang digunakan sebagai wadah video, pemilik akun dapat membubuhkan nama 'TV' pada channel mereka.

\section{Media sosial Instagram Menjadi Platform TV Streaming}

Instagram merupakan bentuk komunikasi yang relatif baru di mana pengguna dapat langsung membagikan status mereka secara langsung dengan mengunggah foto dan dapat dibubuhi dengan filter yang menjadi fitur awal pada saat aplikasi ini diluncurkan (Manikonda, $\mathrm{Hu}, \&$ Kambhampati, 2014). Instagram, tempat berbagi foto online, berbagi video dan layanan jejaring sosial, dengan cepat muncul sebagai media baru yang menjadi sorotan dalam beberapa tahun terakhir. We Are Sosial 2019 juga menyebutkan sejak diluncurkan pada tahun 2010, pengguna Instagram di dunia ada sampai Januari 2019 sebanyak 62 juta orang. Menurut We Are Social 2019, Instagram berada pada urutan 4 (empat) media sosial yang paling diminati dan aktif digunakan di Indonesia dengan penetrasi sebanyak $80 \%$. Pada urutan pertama adalah Youtube dengan penetrasi di angka $88 \%$, dilanjutkan dengan WhatsApp 83\% dan Facebook 81\% (Millward, 2014).

Pada tahun 2018 Instagram menciptkan fitur baru yakni Instagram TV (IGTV). Instagram TV atau merupakan salah satu fitur di Instagram yang memungkinkan pengguna mengunggah 
video dengan durasi yang lebih lama dari IG Story, yakni selama 1 jam. Ada aplikasi tambahan yang diperlukan untuk membuat channel pada Instagram TV. Nantinya, Instagram TV yang telah dibuat akan dengan otomatis terhubung ke dalam Instagram si pengguna. Pengguna juga dapat memilih konten-konten yang akan mereka ciptakan yang nantinya akan ditonton oleh followers mereka.

Instagram menjadi salah satu contoh penggabungan antara media sosial dengan TV kontemporer yang ditunjukkan dengan Instagram TV. Tampilan IG TV pun dibuat menarik dengan unggahan video yang dapat dimuat dengan cukup lebar dan durasi waktu yang lebih lama dibandingkan dengan unggahan video pada feed Instagram (GAMBAR 1). Instagram TV pada media sosial Instagram tentu diminati banyak orang. Saat ini, Instagram TV dapat dibilang sudah bisa bersaing dengan Yotube dan TV Kontemporer. Banyak selebriti di Indonesia mulai memakai Instagram TV sebagai salah satu cara mereka memberikan konten kepada masyarakat. Tidak hanya untuk per-seorangan, bahkan perusahaan dan lembaga pun sudah mulai menggunakan Instagram TV sebagai strategi komunikasi massa mereka.

Salah satu selebriti Indonesia yang menggunakan Instagram TV untuk memberikan informasi dan menambah eksistensi dirinya adalah Gisela Anastasia dengan akun Instagram @gisel_la (GAMBAR 2). Mempertontonkan aksi lucu anak perempuannya yakni Gempita, Gisel memperoleh 1.242.108 penonton dalam videonya sepanjang 1 jam 2 menit tersebut. Konten-konten yang diberikan Gisel kebanyakan berisi konten hiburan dengan Gempita. Dari salah satu contoh konten Instagram TV Gisel pada Gambar 2, ia juga menerima 407 komentar dari penonton Instagram TV-nya tersebut.

Penonton memberikan komentarkomentar yang diberikan langsung dari penonton membuat penonton merasakan bahwa mereka sedang menonton bersama-sama dengan penonton lainnya. Penonton pun bisa mencari informasi, seperti komentar yang diberikan oleh akun@itstia19 yang menanyakan nama permainan yang sedang dimainkan oleh Gempita di konten tersebut. Nantinya, komentar@itstia19 bisa dibalas melalui penonton lain melalui fitur reply (GAMBAR 3).

Cohen dan Lancaster (2014) mengungkapkan bahwa keterlibatan penonton yang bertatap muka langsung dan media sosial dapat diprediksi oleh penularan emosional penonton yang

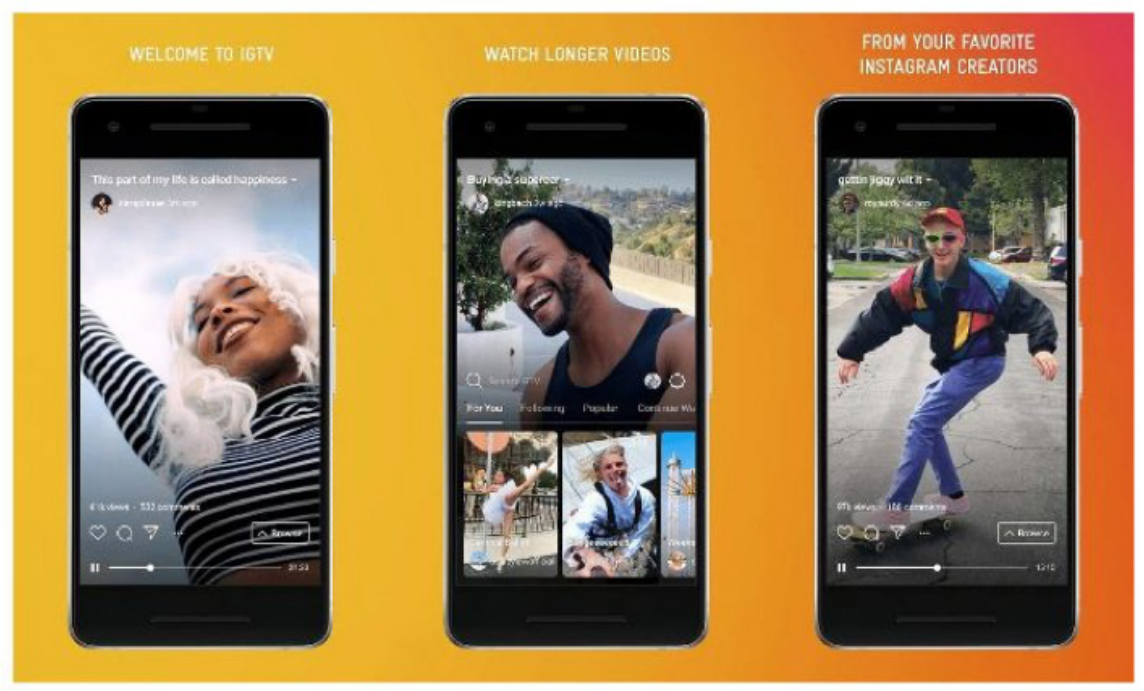

GAMBAR 1. Tampilan IG TV pada platform Instagram Sumber: idcloudhost.com 

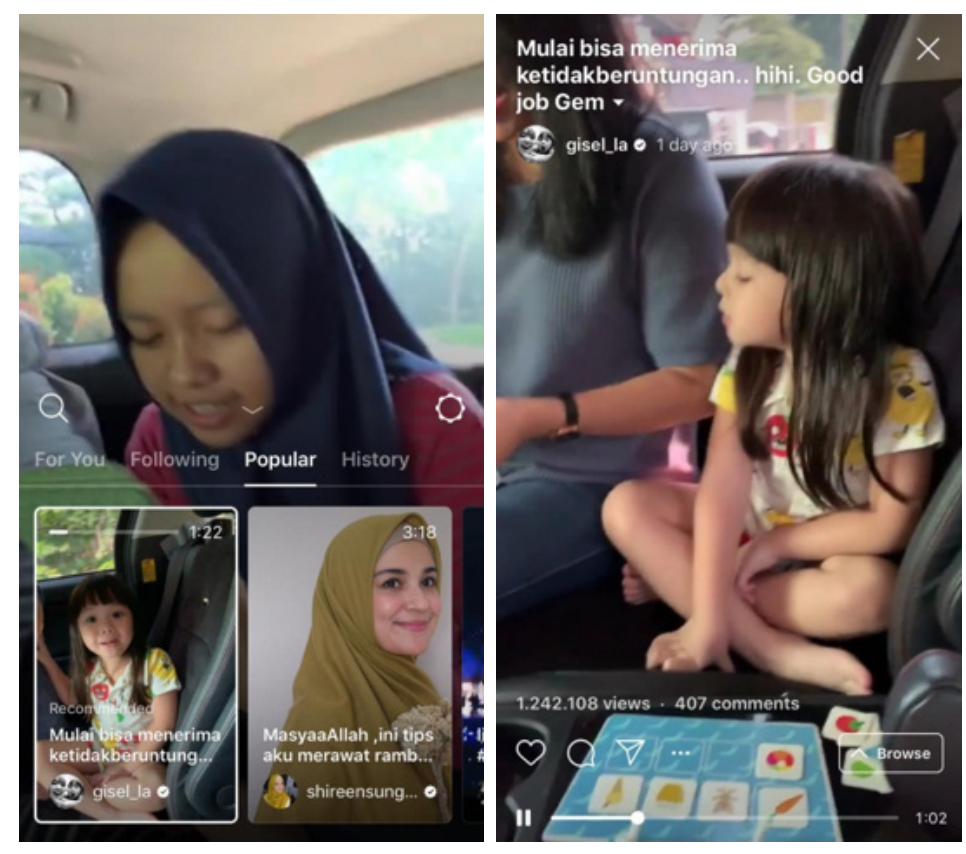

GAMBAR 2. Unggahan video IG TV pada akun@ gisel la

Sumber: Instagram

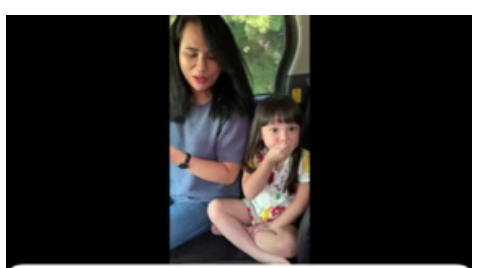

(7) fatmagreen96 Gempi udah cantik pinter, lucu. Paket komplit $\$$ matanya itu loh. Bagus bgt kek pake

1d 11 likes Reply 2. aleyuarth Empiiii $* \odot$

Fi. superprotein_bdg26 Hai Gempitaa id 12 likes Reply itstia19 Itu nama kartu permainnya apa
ya gem $* * 0)$ 1d 10 likes Reply

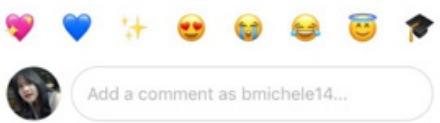

GAMBAR 3. Komentar Penonton IG TV pada Instagram Gisela Anastasia @gisel_la

Sumber: Instagram

berkomunikasi melalui komentarkomentar yang diberikan, kebutuhan mereka untuk menjadi lebih dekat dan menjadi bagian dari si pembuat konten, dan tiga dimensi dari orientasi penayangan, yakni apa saja kebutuhan perusahaan atau si pembuat konten, kebutuhan untuk solitude, dan pemantauan audiens. Lim, Hwang, Kim, dan Biocca (2015) menjelaskan ada tiga tingkat keterlibatan sosial TV (yaitu, fungsional, emosional, dan komunal) pada penonton sosial TV. Hubungan komunal diartikan sebagai loyalitas saluran sosial TV, sedangkan keterlibatan emosional lebih mengarah pada loyalitas saluran melalui peningkatan komitmen dari pembuat konten terhadap penontonnya. Oleh karena itu, penting bagi pembuat konten untuk melibatkan pemirsa dengan kegiatan sosial TV, yang pada gilirannya dapat membantu menjaga konsistensi penayangan dan mengembangkan hubungan ikatan dengan pemirsa.

Dalam akun Instagram @gisel_la yang dimiliki oleh Gisela Anastasia, Gisel

terbilang cukup konsisten mengupload konten INSTAGRAM TV dengan konten keseluruhan rata-rata bersama Gempita. Hubungan komunal konten Instagram TV Gisel terbilang baik. Namun tidak ada kedekatan emosional yang terjalin antara Gisel sebagai pembuat konten dengan penontonnya. Hal ini dibuktikan bahwa tidak adanya komentar-komentar yang dibalas oleh Gisel.

Hal berbeda terjadi dengan Instagram TV milik diva kondang Titi Dwi Jayati atau yang akrab dikenal dengan nama Titi DJ. Instagram TV yang memiliki username@ti2dj dapat dikatakan tidak memiliki kedekatan atau hubungan komunal dikarenakan ia tidak terlalu sering mengupload video dalam Instagram TV. Terbukti sepanjang tahun 2018 sampai 2019, ia hanya memiliki 4 konten di Instagram TV. Namun Titi DJ dapat dikatakan memiliki hubungan emosional yang baik dengan penggemarnya. Hal ini ditunjukkan 
dengan ia terus membalas komentarkomentar yang diberikan penontonnya. Sikap ini dinyatakan baik karena melalui komentar-komentar yang ia balas, ia dapat menjalin hubungan yang lebih harmonis dengan para penggemarnya.

Namun, terjadinya hubungan langsung antara publik figur dengan para penggemarnya melalui komentarkomentar yang disediakan oleh Instagram, dapat juga mengganggu privasi si publik figur itu sendiri lebih dalam lagi. Seperti contoh komentar-komentar negatif yang ditujukan kepada Gisella melalui Sosial TV miliknya di Instagram. Terlihat dari salah satu contoh komentar negatif yang dituliskan oleh akun Instagram @ loekman d yang bertanya bagaimana bahwa Gempi tahu bahwa Wijin adalah orang ketiga dari hubungan Gisel dan mantan suaminya (GAMBAR 4).

\section{Konvergensi Media pada Instagram TV}

Revolusi komunikasi dan teknologi menjadi salah satu faktor yang turut membawa perkembangan baik di dunia penyiaran maupun pers. Internet dengan kelebihannya menyebarkan berita secara global dan massive tanpa batas telah mempengaruhi media massa termasuk kegiatan jurnalistiknya. Media di era digital saat ini adalah media yang sangat maju dan berkembang yang berbasiskan informasi (Fuadi, 2002). Konvergensi media adalah salah satu contoh nyata dari adanya revolusi komunikasi. Revolusi komunikasi melahirkan dunia baru. Kebutuhan informasi untuk manusia dapat diperoleh dengan mudah. Aktivitas informasi dengan cara memproduksi, memproses dan mendistribusikan informasi juga semakin dapat dilakukan oleh siapapun dan dalam waktu kapan pun.

Instagram TV menjadi bentuk dari adanya konvergensi media, yakni penggabungan antara media penyiaran dan media sosial. Konvergensi media adalah bergabungnya atau terkombinasinya berbagai jenis media, yang sebelumnya dianggap terpisah dan berbeda (misalnya, komputer, televisi, radio, dan surat kabar), ke dalam sebuah media tunggal. Gerakan konvergensi media tumbuh berkat adanya kemajuan teknologi akhir-akhir ini, khususnya dari munculnya internet dan digitalisasi informasi (Putri, Hamdan, \& Yulianti, 2017).

Tingkat konvergensi akan tidak merata dalam budaya tertentu, dengan mereka yang paling makmur dan paling melek teknologi menjadi adapter awal dan segmen lain dari populasi yang berjuang untuk mengejar ketinggalan. Konvergensi juga merupakan risiko bagi industri kreatif karena mengharuskan perusahaan media untuk memikirkan kembali asumsi lama tentang apa artinya mengonsumsi media, misalnya asumsi yang membentuk keputusan pemrograman dan pemasaran. Jika konsumen lama diasumsikan pasif,

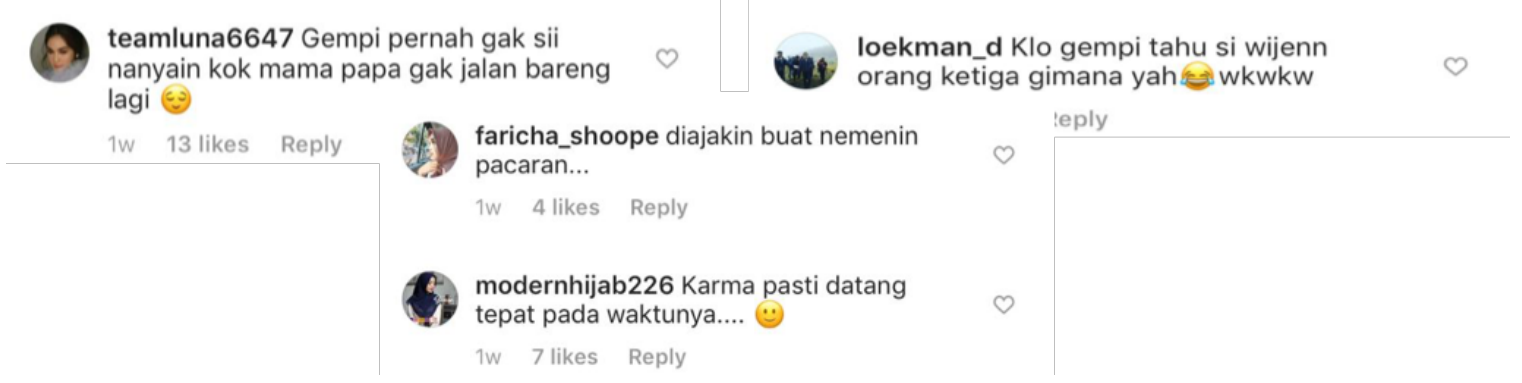

GAMBAR 4. Komentar negatif Penonton INSTAGRAM TV di Instagram Gisela

Anastasia@gisel_la

Sumber: Instagram 
Bianca Michelle Datubara, dkk. Instagram TV: Konvergensi Penyiaran Digital...

konsumen baru bisa bersifat aktif. Jika konsumen lama dapat diprediksi dan diam, maka konsumen baru bermigrasi, menunjukkan loyalitas yang menurun terhadap jaringan atau bahkan media (Jenkins, 2004).

Penyebaran perangkat dan layanan Internet of Things (IoT) semakin cepat dan sebagian besar operator jaringan seluler menganggap jaringan komunikasi Machine-To-Machine (M2M) sebagai sumber pendapatan baru yang signifikan. Hadirnya Instagram TV yang merupakan gabungan antar platform di era digital ini membuat siapapun bisa menciptakan konten TV digital untuk ditonton oleh siapa saja dan disebarkan secara luas. Hal ini biasa disebut dengan user generated content. User generated content adalah sarana penting yang digunakan oleh pengguna internet untuk dapat mengekspresikan diri dan berkomunikasi dengan orang lain secara online (Boyd dan Ellison, 2008). Melalui user generated content ini, konten dapat diproduksi dengan bebas di media sosial tanpa adanya larangan-larangan yang mengikat.

$\begin{array}{ccc}\text { Berbeda dengan televisi } & \\ \text { kontemporer yang memiliki } & \text { Komisi }\end{array}$ Penyiaran Indonesia (KPI) sebagai regulator dan Pedoman Perilaku Penyiaran dan Standar Program Siaran (P3SPS) sebagai kaidah-kaidah yang berlaku dalam penyiaran, belum ada regulasi yang mengatur penyiaran yang berada di ranah digital seperti Sosial TV. Undangundang No.32 Tahun 2002 menyebutkan bahwa penyiaran sebagai kegiatan komunikasi massa mempunyai fungsi sebagai media informasi, pendidikan, hiburan yang sehat, kontrol dan perekat sosial. Instagram TV sebagai sosial TV yang juga merupakan salah satu tools dari komunikasi massa belum memiliki aturan atau pedoman bagaimana konten Instagram TV seharusnya berlaku.

Saat ini, pengawasan internet dilakukan oleh Kementerian Komunikasi dan Informatika dan dilandasi oleh payung hukum dari Undang-undang Nomor 11 Tahun 2008 Tentang Informasi dan Transaksi Elektronik (UU ITE). Namun, masih menjadi perdebatan siapa yang berhak mengawasi video streaming yang sudah menyerupai TV pada media sosial ini. Pasalnya, Komisi Penyiaran Indonesia tidak memiliki wewenang untuk mengawasi penyiaran dalam bentuk streaming.

Andi Andrianto, Koordinator Penelitian dan Pengembangan (Litbang) Komisi Penyiaran Indonesia (KPI) Pusat menyatakan perkembangan dan pergeseran aktivitas broadcasting ini tidak lepas dari adanya aktivitas internet yang sudah mulai tinggi. Hal ini bisa dilihat dari adanya integrasi antara internet dan aktivitas media mainstream. Integrasi tersebut dapat dilihat dengan lahirnya Instagram TV sebagai penggabungan antara media televisi dengan internet atau media sosial.

Misalnya aktivitas broadcasting yang ada di media sosial seperti Instagram TV yang mana kita tahu bahwa aktivitas itu dekat dengan kegiatan-kegiatan broadcasting sebetulnya. Ini menunjukan bahwa distribusi informasi, kemasan informasi, kemudian saluran-saluran dan media tidak hanya terpaku pada media mainstream dalam hal ini radio dan televisi yang lekat dengan aktivitas broadcast. Artinya ada suatu tren baru yang berkembang ke arah media sosial yang sudah semakin banyak digunakan dan diakses oleh masyarakat. (Andrianto, 2019)

Media sosial tentu semakin banyak digunakan untuk berbagai aktivitas. Aktivitas di media sosial pun terbilang bebas sehingga apapun dapat diunggah ke dalam platform media sosial. Kebebasan ini lah yang cenderung sering kali disalahartikan oleh masyarakat. 
Bebas seakan-akan tidak mengindahkan kaidah-kaidah yang berlaku. Pasalnya, tidak adanya regulator di dalam media sosial membuat luas dan massive nya jangkauan media sosial tidak dapat diawasi sampai ke akar-akarnya.

Media sosial belum masuk menjadi ranah pengawasan KPI. Untuk itulah melalui perubahan dan revisi UU Penyiaran ini KPI berupaya untuk juga melakukan usulan kepada DPR RI untuk memasukan poin apakah media sosial ini juga akan diawasi oleh KPI. Karena tanpa regulasi dan dasar hukum yang kuat, tentu KPI tidak bisa menjalankan itu. Jadi intinya adalah KPI sekarang belum melakukan pengawasan terhadap media sosial dimana kontenkontennya jauh juga lebih sebetulnya berbahaya dibandingkan konten yang ada di televisi maupun radio. (Andrianto, 2019)

Sejauh ini persoalan siapakah yang menjadi regulator dari aktivitas media sosial terbilang masih menjadi satu hal yang cukup serius yang harus dibahas dan dicarikan solusinya. Undang-undang No.32Tahun2002 tentang Penyiaranhanya mengamanatkan pengawasan penyiaran atau aktivitas broadcasting kepada media mainstream seperti televisi dan radio, tidak termasuk aktivitas broadcasting yang saat ini sudah terintegrasi kepada media sosial. Hal ini juga dikemukakan oleh Andrianto (2019) bahwa bagaimana pun juga posisi KPI sebagai regulator penyiaran ini punya landasan hukum yang kuat dalam menjalankan tugas dan fungsinya. Berkaitan dengan itu, KPI baru bisa menjalankan fungsi pengawasannya terhadap televisi dan radio karena tidak adanya payung hukum yang menyatakan KPI berhak mengawasi media sosial.

Belum ada pengawasan yang jelas, apalagi sanksi hukum yang diberikan. Jadi relatif jauh lebih bebas. Nah ini yang perlu diwaspadai dan mesti diantisipasi dengan kejelasan regulasi mengenai siapa yang mengawasi dan batasan mana mereka boleh menayangkan konten. (Andrianto, 2019)

Masih banyak kelemahankelemahan yang terdapat pada pasalpasal di UU ITE sehingga banyaknya pelanggaran konten yang ada di media sosial tidak dijerat secara serius. Padahal aktivitas di media sosial pun cukup dapat menimbulkan kesempatan-kesempatan menghadirkan konten yang berbahaya seperti ujaran kebencian, radikalisme, dan kekerasan yang pastinya meresahkan banyak orang. Andrianto (2019) seharusnya ada pembahasan khusus mengenai bagaimana regulasi merespon perkembangan media hari ini yang sudah muncul beberapa tren baru. Pedoman Perilaku Penyiaran dan Standar Program Siaran (P3SPS) yang menjadi pedoman KPI dalam mengawasi penyiaran pun dinyatakan belum dapat digunakan untuk mengawasi aktivitas broadcasting di media sosial.

Sejauh ini P3SPS diturunkan dari UU Penyiaran No.32 Tahun 2002 yang memang masih dengan pola lama. Definisi broadcast-nya pun masih pola lama. Artinya harus ada perubahan definisi dulu, baru ada perubahan poin-poin UU yang diperlukan. P3SPS tentu merespon juga dengan perubahan-perubahan yang baru. P3SPS kita yang hari ini belum merespon soal itu, tentu ini ada pembahasan khusus apakah harus ada aturan baru turunan dari UU Penyiaran yang merespon tentang perkembangan internet dan media sosial tersebut atau dimasukkan ke dalam sub bagian P3SPS untuk membahas soal internet dan media baru itu. Kalau yang sekarang poinnya belum masuk. (Andrianto, 2019) 
Bianca Michelle Datubara, dkk. Instagram TV: Konvergensi Penyiaran Digital...

Tidak hanya dari sisi hukum yang berlaku, untuk pemenuhan fungsi ekonomi dari media penyiaran digital Instagram TV ini pun tidak berpatokan pada iklan. Media televisi kontemporer menggunakan iklan sebagai pemasukan mereka. Namun, dalam Instagram TV, iklan bukan satu-satunya cara mereka menghasilkan keuntungan. Oleh karena itu, media televisi nasional yang mengandalkan iklan sebagai satu-satunya sumber pendapatan harus mencari alternatif lain agar dapat bertahan dan bersaing dengan industri media lainnya (Sumartias \& Hafizni, 2018). Seakan takut kalah bersaing di dunia digital, saat ini televisi-televisi nasional pun sudah mulai mencoba untuk melakukan produksinya dengan bergeser kepada ranah digital atau streaming.

$$
\begin{aligned}
& \text { Selain kualitas presentasi dan } \\
& \text { program, penerapan konvergensi }
\end{aligned}
$$
media adalah cara untuk tetap unggul dalam persaingan di industri media televisi. Negroponte mengatakan bahwa kombinasi industri media tradisional dan industri komputer akan menciptakan jenis komunikasi baru (Sumartias \& Hafizni, 2018). Hal ini lah yang sudah menjadi prediksi industri teknologi komunikasi dari tahun ke tahun, yakni bergabungnya media tradisional dan industri komputer. Namun konvergensi media pada media penyiaran harus dikawal dengan adanya regulator di setiap negara agar konten yang disajikan tetap sesuai dengan nilai-nilai kebangsaan. Di Belanda, taruhan antara penyiar publik dan media sosial tercermin dalam potensi stasiun media sosial yang mempertimbangkan keterlibatan audiens dengan niat komersial dan intervensi teknis yang tidak sesuai dengan nilai-nilai publik (Van Dijck \& Poell, 2015). Hal ini tidak boleh terjadi di Indonesia.

Salah satu dampak dari konvergensi media yang lain adalah masyarakat terus-menerus meninggalkan media tradisional, hal ini termasuk koran atau TV dan terus bergeser ke arah online. Faktor paling penting yang menarik masyarakat ke arah digital ini adalah kenyataan bahwa mereka dapat memilih konten yang mereka inginkan pada saat mereka menginginkannya (Nikas, Alepis, \& Patsakis, 2018). Selain itu, konten digital dapat dinikmati dimana saja dengan segala kecanggihan yang dimilikinya.

Bahkan lebih buruk daripada kehilangan pemirsa atau penonton, konvergensi media juga menimbulkan pergeseran produser penyiaran. Semakin banyak dari masyarakat akan lebih tertarik dengan potensi inovatif dari produksi multiplatform. Ruang internet juga memberikan suatu anugerah bagi produsen independen yang dan para pengusaha yang ingin membuat dan mendistribusikan program web khususnya media penyiaran berbasis digital (Van Dijck \& Poell, 2015).

Konvergensi media penyiaran digital dengan media sosial seperti Instagram Tv menyuguhkan lebih banyak audiens dengan pilihan koten yang juga lebih banyak macamnya. Tidak hanya perihal produksi dan konsumsi, konvergensi media juga menjadi tanda akan perubahan dari berbagai bidang komunikasi termasuk media, budaya, khalayak, teknologi, dan industri (Sumartias \& Hafizni, 2018). Lebih banyaknya khalayak yang terjun kepada dunia media digital tentu mempengaruhi setiap pergerakan di dunia tradisional.

Konvergensi media bagaimanapun diprakarsai oleh teknologi digital. Konvergensi media ini lebih dari sekedar penggabungan dari media namun lebih dalam konvergensi media dalam arti konvergensi konten, konvergensi teknologi, dan terutama konvergensi peran, yang telah terjadi tidak hanya di perusahaan media yang bergabung maupun yang tidak, seperti Instagram TV yang hanya menggabungkan dua konsep 
media massa menjadi satu (Huang, 2006). Oleh karena itu, konvergensi media harus terus diawasi.

\section{SIMPULAN}

Adanya konvergensi media dan penggabungan antar platform seperti media mainstream dan media sosial merupakan salah satu keunggulan penggunaan internet pada saat ini. Sosial TV yakni Instagram TV menjadi salah satu contohnya. Konvergensi media adalah bergabungnya atau terkombinasinya berbagai jenis media, yang sebelumnya dianggap terpisah dan berbeda (misalnya, komputer, televisi, radio, dan surat kabar), ke dalam sebuah media tunggal. Konvergensi media penyiaran digital dengan media sosial seperti Instagram Tv menyuguhkan lebih banyak audiens dengan pilihan koten yang juga lebih banyak macamnya. Tidak hanya perihal produksi dan konsumsi, konvergensi media juga menjadi tanda akan perubahan dari berbagai bidang komunikasi termasuk media, budaya, khalayak, teknologi, dan industri (Sumartias \& Hafizni, 2018). Lebih banyaknya khalayak yang terjun kepada dunia media digital tentu mempengaruhi setiap pergerakan di dunia tradisional. Konvergensi media ini lebih dari sekedar penggabungan dari media namun lebih dalam konvergensi media dalam arti konvergensi konten, konvergensi teknologi, dan terutama konvergensi peran, yakni peran platformplatform yang bergabung menjadi satu.

Adanya konvergensi media salah satunya Instagram Tv memungkinkan masyarakat untuk memiliki channel TV pribadi dan dapat membuat kontennya secara bebas. Namun, belum adanya regulasi yang menekankan konsekuensikonsekuensi hukum yang menjadi pedoman dari konten di Instagram Tv ini dapat menciptakan konten-konten yang tidak sesuai dengan kaidah Pancasila, baik pada konten penyiaran maupun komentar dengan bahasa-bahasa tidak pantas yang ditujukan kepada publik figur atau orang yang mengunggah konten pada Instagram Tv. Pasalnya Komisi Penyiaran Indonesia (KPI) sebagai regulator penyiaran tidak diberikan wewenang untuk mengawasi aktivitas broadcasting di bidang internet, termasuk media sosial. Pemerintah harus mengambil langkah guna mengantisipasi dampak-dampak negative darikonvergensi media penyiaran digital dan media sosial, salah satunya adalah konten-konten yang berbahaya bagi kedaulatan negara.

\section{DAFTAR PUSTAKA}

Binns, D. (2019). The Netflix documentary house style: Streaming TV and slow media, (December 2018).

Boyd, D. M., \& Ellison, N. B. (2008). Social Network Sites: Definition, History, and Scholarship. Journal of ComputerMediated Communication, 13, 210-230

Choi, S. M., Wong, S. F., Chang, Y., \& Park, M. C. (2016). Analysis of the dynamic broadband technology competition Implications for national information infrastructure development. Industrial Management and Data Systems, 116(6), 1223-1241. https://doi.org/10.1108/ IMDS-09-2015-0394

Fuadi, M. E. (2002). Surat Kabar Digital sebagai Media Konvergensi di Era Digital. MediaTor.

Huang, E., Davison, K., Shreve, S., Davis, T., Bettendorf, E., \& Nair, A. (2006). Facing the challenges of convergence: Media professionals' concerns of working across media platforms. Convergence, 12(1), 83-98. https://doi. org/10.1177/1354856506061557

Hwang, Y. C., \& Lim, J. S. (2015). The impact of engagement motives for social TV on social presence and sports channel commitment. Telematics and Informatics, 32(4), 755-765. https://doi. org/10.1016/j.tele.2015.03.006

Jenkins, H. (2004). The Cultural Logic of Media Convergence. International Journal of Cultural Studies, 7(1), 33-43. https:// doi.org/10.1177/1367877904040603 
Bianca Michelle Datubara, dkk. Instagram TV: Konvergensi Penyiaran Digital...

Kim, J., Yang, H., \& Kim, J. (2019). Being social during the big dance: Social presence and social TV viewing for March Madness in public and private platforms. The Social Science Journal. https://doi. org/10.1016/j.soscij.2019.04.004

Li, Y., Zhang, Y., \& Yuan, R. (2011). Measurement and analysis of a large scale commercial mobile internet TV system, 209. https://doi. org/10.1145/2068816.2068837

Lin, T. C. (2018). The Gordian Knot of Singapore 's Mobile TV Policy, Journal of International Commercial Law and Technology, 5 ( 1 ), 11-21 . ( A good journal ranked by the law school, Sydney Technologica ... The Gordian Knot of Mobile TV Policy in Singapore, 5(January 2010), 11-21.

Manikonda, L., Hu, Y., \& Kambhampati, S. (2014). Analyzing User Activities, Demographics, Social Network Structure and User-Generated Content on Instagram. Retrieved from http://arxiv.org/ abs/1410.8099

Millward, S. (2014). Indonesia diproyeksi lampaui 100 juta pengguna smartphone di 2018, keempat di dunia. https://id.techinasia.com/jumlah-pengguna-smartphone-di-indonesia-2018, diunduh pada 16 Mei 2019

Neuman, W. Laurence. (2017). Metodologi Penelitian Sosial: Pendekatan Kualitatif dan Kuantitatif. Jakarta: PT Indeks.

Nikas, A., Alepis, E., \& Patsakis, C. (2018). I know what you streamed last night: On the security and privacy of streaming. Digital Investigation, 25, 78-89. https:// doi.org/10.1016/j.diin.2018.03.004

Putri, D. W., Hamdan, S. R., \& Yulianti, Y. (2017). Perilaku Bermedia Digital Dalam Pelaksanaan Tridharma Perguruan Tinggi Dikalangan Dosen Unisba. Mediator: Jurnal Komunikasi, 10(1), 1124. https://doi.org/10.29313/mediator. v10i1.2731

Shin, D. H. (2013). Defining sociability and social presence in Social TV. Computers in Human Behavior, 29(3), 939-947. https://doi.org/10.1016/j. chb.2012.07.006

Somantri, G. R. (2004). Out-source call center operates in the Moscow region. Elektrosvyaz, 9(5), 26. https://doi. org/10.7454/mssh.v9i2.122

Sugiyono. 2009. Metode Penelitian Kuantitatif, Kualitatif dan R\&D. Bandung: CV Alfabeta.

Sumartias, S., \& Hafizni, M. (2018). Convergence Trends in the Television Media Industry - A Case Study on the Implementation of Media Convergence in Metro TV Jakarta. KnE Social Sciences, 2(4), 83. https://doi.org/10.18502/kss. v2i4.871

Van Dijck, J., \& Poell, T. (2015). Making public television social? Public service broadcasting and the challenges of social media. Television and New Media, 16(2), 148-164. https://doi. org/10.1177/1527476414527136 